УДК 351.77

B. B. Kaрлаш, здобувач, Навчально-науково-виробничий чентр

Начіонального університету иивільного захисту України

ORCID ID: 0000-0002-8092-1189

DOI: $10.32702 / 2306-6814.2020 .1 .161$

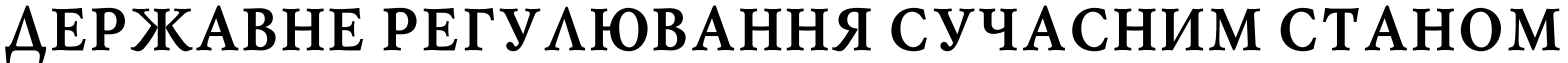 ОХОРОНИ ЗАОРОВ'Я УКРАЇНИ
}

\author{
V. Karlash, \\ applicant of the Educational, Scientific and Production Center of the National University of Civil Defense of Ukraine, Kharkov
}

\section{STATE REGULATION OF THE CURRENT STATE OF HEALTH CARE IN UKRAINE}

У статті розкриваються особливості сучасного стану системи охорони здоров'я в Україні, яка представляє собою складну соціально-економічну сферу, спрямовану на реалізацію одного з важливих соціальних принципів - збереження та поліпшення здоров 'я громадян, а також надання висококваліфікованої лікувально-профілактичної допомоги.

Автор зазначає, що державне регулювання галузі охорони здоров 'я займає важливу позицію в політиці держави, за якої основна мета полягає у розвитку галузі шляхом підвищення ефективності діяльності системи й виконання принципу доступності надання медичної допомоги населенню.

У статті автор вказує на ключові проблеми в системі охорони здоров'я України на сучасному етапі проведення реформи та розвитку галузі. Водночас автор відзначає, що головний результатдержавного регулювання в сфері охорони здоров'я пов 'язаний зі створенням реальних умов діяльності медичних установ, які будуть сприяти наданню позитивного ефекту на здоров'я населення та досягати цільових показників у сфері охорони здоров'я.

The article reveals the features of the current state of the health care system in Ukraine, which is a complex socio-economic sphere aimed at the implementation of one of the important social principles - the preservation and improvement of citizens' health, as well as the provision of highly qualified medical and preventive care. The organization of the health care system is carried out through public administration, including: regulatory legal regulation, development and implementation of measures to prevent the occurrence and spread of diseases, including socially significant and diseases that are dangerous to others, the formation of a healthy lifestyle of the population and is based on the functioning and the development of public and private health systems.

The author notes that government regulation of the health care industry has an important position in state policy, in which the main goal is to develop the industry by improving the efficiency of the system and implementing the principle of accessibility of medical care to the population.

The author also points out that in modern conditions the implementation of the strategic goals of the health care system in Ukraine faced with a complex of problems of a political, economic, demographic, technological and environmental nature.

Under such conditions, a conflict of interests arises and deepens, which consists in a mismatch between the tasks that healthcare systems face in increasing the availability and quality of services, ensuring equality, fairness, and financial and economic possibilities for their implementation. In order to achieve other qualitative results, it is necessary to systematize the causes and propose sound solutions aimed at improving the quality of medical services with modern management tools and instruments of state regulation of health care.

In the article, the author points to the key problems in the health care system of Ukraine at the present stage of the reform and development of the industry. At the same time, the author notes that the main result of state regulation in the field of health care is associated with the creation of real conditions for the activities of medical institutions, which will contribute to a positive effect on public health and achieve health targets.

КлючоВі слоВа: держаВне регулюВання охороною здороВ'я, система охорони здоров'я, проблеми охорони здоров'я, медична реформа, медичні послуги.

Key words: state regulation of health care, the health care system, health problems, medical reform, medical services.

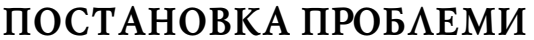

Умови сучасного розвитку України передбачають формування нових критеріїв соціальної справедливості, які дозволять забезпечувати рівний і справедливий до- ступ до медичних послуг, досягати їх високої якості та підвищувати ефективність діяльності галузі при задоволенні населення медичною допомогою. Система охорони здоров'я повинна бути соціально спрямованої, 
сприяти збереженню і розвитку потенціалу здоров'я громадян як одного з визначальних критеріїв суспільного розвитку.

Одним з ключових соціально-економічних питань, який виходить на перший план у системі державного регулювання охороною здоров'я, $є$ недостатньо висока якість медичних послуг. У зв'язку з цим підвищення якісних параметрів медичного обслуговування стає актуальною проблемою, яка вимагає пошуку нових рішень для досягнення якісних результатів за рахунок використання сучасних управлінських інструментів.

\section{АНА $А$ ОСТАНHIX АОСЯГНЕНЬ І ПУБ АІКАЦІЙ}

Багато дослідників сьогодні вивчають проблему забезпечення населення України якісними охороною здоров'я та медичним обслуговуванням. Середних можна назвати М.М. Білинський, В.Ф. Москаленко, І.М. Солоненко та ін. Серед напрямів їх досліджень передусім виділяється державне управління реформуванням системи охорони здоров' я України, створення автономності установ охорони здоров'я, вдосконалення правових основ та економічного забезпечення галузі.

Однак питання державного регулювання забезпечення послуг охорони здоров'я на сучасному етапі реорганізації всієї системи забезпечення охорони здоров'я України вимагають додаткового вивчення основних проблем, що виникають при реформуванні будь-якій галузі економічної та соціальної сфери.

\section{META CTATTI}

Мета статті полягає в дослідженні основних питань та проблем у державному регулюванні системою охорони здоров'я України на сучасному етапі її розвитку, а також розробки напрямів вирішення таких проблем.

\section{ВИКААА ОСНОВНОГО МАТЕРІААУ}

Система охорони здоров'я включає в себе всі організації, інститути і ресурси, які направлені на зміцнення, підтримку і відновлення здоров'я. Метою системи охорони здоров'я виступає поліпшення здоров'я всього населення, досягнення відповідність запитам і потребам людей, забезпечення справедливого розподілу фінансових ресурсів, доступність всіх до наявних ресурсів. Забезпечення ефективного фрункціонування системи охорони здоров'я здійснюється нормативно-правовою базою, яка включає в себе комплекс ресурсів, що розділяються також на фрінансові, кадрові, матеріально-технічні, керуючі та технологічні [5].

Для досягнення основних цілей охорони здоров'я населення держава здійснює регулюючу діяльність, яка безпосередньо залежить від виконання ключових функцій. Серед них ми можемо назвати фрункцію направляючого керівництва, формування ресурсів, надання послуг і фінансову.

Однак сучасні умови реалізації цих цілей системи охорони здоров'я в нашій країні характеризується рядом проблем, пов'язаних з політичною, динамічної, демографрічної, технологічної та екологічної ситуацією. Зростання темпів старіння населення, зміна протікання хвороб на переважно хронічний характер, ведення нездорового способу життя, призводять до підвищення потреби в отриманні медичного обслуговування, тим самим позначається на зростанні витрат і ресурсів [4].

Крім цього, постійний розвиток нових медичних технологій і підвищення рівня освіченості з питань здоров'я, збільшує вартість медичної допомоги, що в свою чергу, викликає підвищення очікувань населення за якістю такого обслуговування. Разом з цим для України характерна наявність випереджаючого темпу зростання витрат на медичну допомогу в порівнянні з темпами збільшення ВВП країни, а кризові явища визначають необхідність пошуку шляхів зниження витрат і раціонального використання ресурсів [1].

Всі ці умови провокують і поглиблюють конфлікт інтересів, який полягає в наявності невідповідності між завданнями, що стоять перед системою охорони здоров'я по підвищенню доступності та якості послуг, забезпечення рівності, справедливості, з фрінансово-економічними можливостями їх реалізації [2].

На сучасному етапі розвитку системи охорони здоров'я основні цілі механізму державного регулювання сорери, враховуючи названі проблеми, представлені такими напрямами:

- забезпечення населення висококваліфікованими фрахівцями та якісним рівнем медичного обслуговування;

- забезпечення громадян гарантованим пакетом безкоштовних медичних послуг;

- забезпечення достатнього рівня фрінансового забезпечення;

- забезпечення новими технологіями та інноваційним розвитком галузі;

- вдосконалення системи організації та управління охороною здоров'я;

— підвищення рівня кваліфікації кадрів у системі охорони здоров'я;

- проведення профрілактичної діяльності;

- забезпечення вдосконалення процесу правового регулювання;

- створення конкурентного середовища на медичному ринку;

- створення системи охорони здоров'я, яка пристосовується до постійно змінюваних умов існування економічного ринку.

Для досягнення поставлених завдань важливим моментом $€$ те, що органи влади, здійснюючи державне регулювання сорери охорони здоров'я спираються на такі принципи, як законність, прозорість, системність, оптимальність, прогнозованість, пріоритетність, ефективність і соціальна відповідальність. Дотримуючись зазначених принципів, можна досягати підвищення дієвості та ефективності механізму державного регулювання в умовах рефрормування галузі, існуючі на цьому етапі в Україні.

Водночас важливо враховувати, що для досягнення високої результативності державного регулювання в сорері охорони здоров'я, необхідно дотримуватися ряду принципів, показників та причин [3]. Найважливішою умовою що забезпечує ефективне функціонування сорери охорони здоров'я $€$ наявність дієвого інструментарію регулювання процесів, що відбуваються в цій сорері. Тобто завдання інструментарію - забезпечити такі умови, які будуть запобігати негативним наслідкам.

Українська система, безперечно, одна з найслабших серед посткомуністичних європейських держав. Вона 
характеризується організаційною та фрінансовою неефективністю, неадекватністю потреб населення в охороні здоров'я та відсутністю більш глибоких зусиль 3 реформування протягом посткомуністичного перехідного періоду. Всі ті зміни, що відбувалися і спрямовувалися на модернізацію існуючих рішень (впровадження моделі сімейної медицини в первинну медичну допомогу, зміна методів фінансування послуг, запровадження додаткових механізмів фінансування) носили суто початковий характер, впроваджуючись лише в деяких областях, або як свого роду пробний механізм. Все це відображається в низькому рівні реагування на медичні потреби окремих осіб і груп, що також призводить до погіршення стану здоров'я населення країни.

Система характеризується низькими рейтингами не тільки у сорері охорони здоров'я, але і з точки зору доступу до послуг, де однією з головних перешкод $є$ фінансова проблема, рівність та справедливість, а також відсутність реалізації заходів, спрямованих на позитивне стимулювання здоров'я населення країни. Складна політична та економічна ситуація в країні $€$ додатковими фракторами, які створюють перешкоди для ефективного підвищення ефективності системи. Низький рівень ВВП не забезпечує адекватної фрінансової підтримки, а геополітична та економічна нестабільність останніх років додатково призвела, як і слід було припустити, до краху сектора деяких послуг.

Остання політична революція в Україні (2014р.) знову відкрила шанс реалізувати проект глибокої модернізації української держави. Політичні лідери чітко заявили про волю до проведення такого амбіційного проекту, і одним з симптомів такої взаємодії було бажання замінити еліти, що приймають рішення. Шлях до досягнення цієї мети полягав у інтенсивному наборі осіб з інших країн на керівні посади в державному управлінні та інших централізовано керованих організаціях.

Цей ентузіазм реформування також стосується анахронічної структури системи охорони здоров'я. У 2015 році Україна, як перший крок реформ, передала міжнародним організаціям закупівлі вакцин, медикаментів та медичного обладнання: Дитячий фонд ООН (ЮНІСЕФ), Програма розвитку ООН (ПРООН) та британська некомерційна організація Crown Agents. У тому ж році Міністерство охорони здоров' я, яке очолює народжений Грузією Олександр Квіташвілі, а потім і Ульяна Супрун, яка народилася в США, запропонувала пакет рефрорм, заснований на п'яти основних стовпах.

Першою опорою концепції Міністерства було реорганізація системи фрінансування медичних послуг, де головна зміна - перекласти раніше застосовану модель фінансування закладів на фінансування потреб пацієнта відповідно до популярного фрормулювання "гроші йдуть за пацієнтом". Це зміна, яку слід розглядати як спробу застосувати рішення, які раніше застосовувалися в інших посткомуністичних країнах. Ії̈ основні припущення передбачають необхідність змінити відносини між платником та суб'єктами, які надають медичні послуги, де останні змушені пристосовуватися до умов, запропонованих платником. Вони, згідно з припущеннями, повинні бути отримані з реальних потреб населення. Іншими словами, спектр послуг, що надаються постачальниками, та їх кількість повинна бути виведена з діагностованих потреб у охороні здоров'я, а також ре- зультатів споживчих рішень щодо вибору об'єкта, що також відкриває українську систему для внутрішньої конкуренції.

Другий рівень Міністерства полягав у впровадженні медичної спеціалізації у сорері сімейної медицини. Сімейний лікар, з одного боку, повинен стати головним координатором процесу охорони здоров'я пацієнта, а з іншого - підлягає вибору пацієнта на індивідуальній основі, на відміну від поточної конструкції, яка базується на системі реонізації з радянських часів. Крім того, фрінансування сімейного лікаря повинно базуватись на показниках на душу населення, де доходи лікаря залежать від кількості пацієнтів, про які йдеться, що перебувають під його опікою. Це такожє рішенням, що стосується проектів, які раніше виконувалися в інших посткомуністичних країнах.

Наступним елементом концепції Міністерства було те, що держава зобов'язується чітко визначити обсяг своєї фрінансової відповідальності у сфері охорони здоров'я, яка повинна розглядатися як рівнозначна запровадженню пакету гарантованих пільг. Згідно з декларацією Міністерства охорони здоров'я України, повний спектр відшкодування передбачається для охоплення сімейних медичних послуг, паліативної допомоги, екстреної медицини та фрармацевтичного лікування серцево-судинних захворювань, бронхіальної астми та діабету 2 типу. Нарешті, повною мірою відповідальність держави також стосується пологів, рідкісних захворювань та онкологічного лікування. Очікувалося, що такі рішення допоможуть роз'яснити фінансову відповідальність держави, а також обмежити феномен неформальних платежів, які зазвичай з'являються в системі охорони здоров'я.

В інших сорерах, не включених до пакету повністю гарантованого обслуговування, передбачається запровадити систему доплати, включаючи тарифи, затверджені державою та що залишилися в межах її регулювання, а також систему додаткового страхування. Водночас певний спектр послуг повинен бути повністю виключений з ряду державно фрінансованих вигод (наприклад, естетичної медицини). І ця ідея стала четвертою опорою концепції Міністерства.

Останнім ключовим елементом бачення реформи Міністерства були характеристики та якість наданих послуг, де, найголовніше, що лікарі, котрі працюють у системі, повинні бути зобов' язані впроваджувати процедури відповідно до сучасних міжнародних стандартів, замість існуючих, які застаріли та $€$ неадекватні нинішньому стану медичних знань. Досі застосовувані процедури також схильні до шахрайства та корупції - лікування деяких захворювань дорогими танеадекватними лікарськими засобами призводить не стільки від реальних потреб у сфері охорони здоров'я, скільки від неформальних домовленостей, які надають фрінансові пільги конкретним особам (у тому числі урядовці, які приймають рішення про застосування даної процедури). Проблема також пов'язана з реформою медичної освіти, насамперед шляхом забезпечення доступу до останніх досягнень угалузі медичних наук, а також усуненням корумпованої системи надання права на здійснення медичної професії та надання об'єктивна, зовнішня система оцінки компетентності випускників.

Серед припущень, пов'язаних із системними змінами, які український уряд планує реалізувати, є й такі, що 
розташовані між перерахованими стратегічними цілями. Однією з них є передбачувана зміна моделі розподілу та здійснення вакцинації. Нині постачання базується на спеціальних закупівлях, які мають бути замінені на трирічну систему планування. З одного боку, таке рішення повинно збільшити доступність вакцин для пацієнтів, а з іншого - усунути зловживання, пов'язані з придбанням вакцин. Міністерство охорони здоров'я також планує модернізувати установи, що надають медичні послуги, та широко застосовувати комп'ютеризацію системи охорони здоров'я, яка повинна включати можливість для пацієнтів використовувати онлайн-реєстрацію.

Крім того, Україна заявляє про свою готовність реалізовувати перспективу охорони здоров'я в оцінці політики, що застосовується в інших сферах діяльності держави, включаючи сферу фіскальної політики та використання її інструментів для стимулювання поведінки для здоров'я.

Нормативний механізм вдосконалення державного управління сфрерою охорони здоров'я на сьогодні представлений вирішенням питань державної політики України, пов'язаної з проведенням медичної реформи. Так, гостро стоїть питання визначення викликів, проблем іпереваг нової системи охорони здоров'я і виявлення найбільш оптимальних шляхів її розвитку. І одним з найважливіших питань виступає ефективне нормативне регулювання галузі.

Як зазначалося вище, початок медичної реформи в Україні пов'язан з прийняттям у 2017 році Закону України "Про державні фрінансові гарантії медичного обслуговування населення". 3 початку прийняття цього закону виникає питання про неконституційність його положень, що призвело до появи прохання суб'єктів права на конституційне подання до Конституційного Суду України на підставі статті 75 Закону України "Про Конституційний Суд України". Це призвело до виникнення спірних моментів, коли, з одного боку, суду необхідно було підтвердити основоположні гарантії прав людини, а з іншого - прийняти законність норм, пов'язаних зі змінами національної моделі охорони здоров'я.

\section{ВИСНОВКИ ТА ПЕРСПЕКТИВИ ПОАА}

Таким чином, державне регулювання в сорері охорони здоров'я, $є$ сукупністю організаційно-економічних механізмів впливу держави на діяльність продуцентів послуг сорери охорони здоров'я, мета яких - надання якісних і доступних послуг; воно сприяє підвищенню стійкості до впливів зовнішнього середовища і розвитку галузі. Держава здійснює регулювання сфери послуг охорони здоров'я на основі нормативно-правових актів, що встановлюють структуру органів державного регулювання послуг сфрери охорони здоров'я, правове становище продуцентів послуг сфери охорони здоров'я та охорону їх власності, порядок укладення та виконання господарських договорів, правила надання послуг, захист прав споживачів таких послуг, питань, пов'язаних з етичної стороною організації надання послуг. Державне втручання у функціонування сфери послуг охорони здоров'я включає такі напрями: вдосконалення нормативного регулювання діяльності продуцентів послуг охорони здоров'я (наприклад, регулювання правил надання послуг), створення сприятливого інвестиційного політики та її інформаційного супроводу, вдосконалення системи державних замовлень, надання гарантій і субсидій, надання пільг по оподаткуванню, підготовку кваліфікованих медичних кадрів, регулювання цін і тарифрів на послуги галузі, сприяння формуванню ринкових інститутів, індикативного планування і прогнозування, надання продуцентів послуг сфери охорони здоров'я певної економічної самостійності.

\section{Література:}

1. Гладун 3.С. Адміністративно-правове регулювання охорони здоров'я населення в Україні: монографія / З.С. Гладун. - К.: Юрінком Інтер, 2007. - 720 с.

2. Долот В.Д. Система охорони здоров'я в Україні: шляхи виходу з кризи [Електронний ресурс] / В.Д. Долот / / Ефрективність державного управління. - 2014. Вип. 38. - С. 184-190.

3. Реформування системи охорони здоров'я на муніципальному рівні: навч. посіб. / І.М. Солоненко, О.П. Попов, Л.І. Жаліло, К.О. Надутий. - К.: Вид-во НАДУ, 2017. - 211 с.

4. Савостьянова С.Л. Особливості державного регулювання механізмів суспільного розвитку у сфері забезпечення населення України послугами з охорони здоров'я / С.Л. Савостьянова / / Проблеми управління соціальним і гуманітарним розвитком: IV регіон. 236 наук.-практ. конф. за міжнар. участю, 26 листоп. 2010 р.: тези доп. - Дніпропетровськ: ДРІДУ НАДУ, 2010. - С. 271-274.

5. Фуртак І. Правове забезпечення раціоналізації державного управління системи охорони здоров'я України / І. Фуртак, А. Варава / / Науковий вісник. 2010. - Вип. 6 "Демократичне врядування".

References:

1. Gladun, Z. S. (2007), Administrativno-pravove regulyuvannya ohoroni zdorov'ya naselennya v Ukrayini: monografiya [Administrative and legal regulation of public health in Ukraine: monograph], Vid-vo Odyssey, Moskow, Russia.

2. Dolot, V. D. (2014), "Health system in Ukraine: ways out of the crisis", Efektivnist derzhavnogo upravlinnya, vol. 38, pp. 184-190.

3. Solonenko, I.M. Popov, O.P. Zhalilo, L.I. and Inflatable, K.O. (2017), Reformuvannya sistemi ohoroni zdorov'ya na municipalnomu rivni: navch. posib [Reforming the health care system at the municipal level: training. manual], Vid-vo NADU, Kyiv, Ukraine.

4. Savostyanova, S.L. (2010), "The peculiarities of state regulation of mechanisms of social development in the sphere of providing population of Ukraine services in health care", Problemi upravlinnya socialnim i gumanitarnim rozvitkom: IV region. 236 nauk.-prakt. konf. za mizhnar. Uchastyu [Problems of social and humanitarian development management: IV regional science-practice. Conf. for the international. participation], DRIDU NADU, Dnipropetrovs'k, Ukraine, 26 nov., pp. 271-274.

5. Furtak, I. and A. Varava, (2010), "Legal support for rationalization of public administration of the health care system of Ukraine", Democratic Governance. Naukovij visnik, vol. 6 .

Стаття надійшла до редакчї 03.01.2020 p. 